just which, we are told, is as "a shining light, that shineth more and more unto the perfect day."

\author{
Sic itur ad astra.
}

\title{
ERNEST HART.
}

We deeply regret to chronicle the death of Mr. Ernest Hart. Although his own personal interest lay chiefly in matters connected with Public Health, and his editorial duties led him into every department of Medicine, he was ever alive to the claims of our specialty. In his official capacity as editor of the British Medical Journal, and as Chairman of the Parliamentary Bills Com. mittee of the British Medicul Association, he was always accessible and willing to lend us a helping hand. Mr. Hart's energy and enterprise were unbounded; his determination to leave the world better than he found it was worthy of all praise. We might object to certuin incidents in his cureer and certain methods in his working; but when the measure of his achievements is reckoned. his mistakes are obliterated by a sense of his personal worth, and the loss which the medical profession has sustained by his death.

\section{THE LIBRARY.}

The Library Committee usks for the following to complete sets, viz. -

Reports of the Commissioners in Lunacy for England and Wales for the years 1847, ' 48, ' 49, ' 64 , and '74.

Reports of the Scottish Commissioners, Nos. 3, 4, 6, 8, 10, 11, 13, 18.

American Journal of Insanity for the year 1886.

Archives de Neurologie for the yeurs 1874-5-6-7, and 1887.

L'Encephale, from 1888.

Allgemeine Zeitschrift für Psychiatrie. Complete set wanted.

Annales Médico.Psychologique, 1864-5-6.

\section{NOTICES BY THE REGISTRAR.}

At the examination for the certificate in Psychological Medicine held on December 16th, 1897, the following candidates were successful :

Examined at Bethlehem Royal Hospital, London.-Oscar Bernard Goldschmidt, William John Handfield Haslett, Robert Hughes, George McGregor.

Examined at the Royal Asylum, Morningside, Edinburgh.-Charles Cromball Easterbrook, G. Landsborough Findlay, Donald A. Macvean.

Examined at the District Asylum, Cork.-Lucia Strangman.

The following is a list of the questions which appeared on the paper:

1. How would you treat persistent insomnia $(a)$ in passive melancholia ; $(b)$ in melancholia with excessive bodily movement; $(c)$ in rcute mania? 2 . What forms of mental disease are associated with a previous history of syphilis ? How far do you consider general paralysis of the insane to be due to syphilis ? 3 . Enumerate the principal varieties of mental disease arising from alcoholic excess, and give the distinguishing physical syınptoms of each variety. 4. Give examples of mental and physical causes of refusal of food, the prognosis in each, and the indications for treatment. 5. Distinguish between idiocy, imbecility. dementia, and stupor, and give the best recognised classification of idiocy. 6 . Compare the changes in the brain cells which have been described as characteristic respectively of paretic, senile, and alcoholic dementia. To which conjecture as to the mode of origin of these respective changes do you incline, and why?

The next examination will be held in July, 1898. 
The examination for the Gaskell Prize will take place at Bethlem Hospital in the same month.

The exact dates for these examinations have not yet been fixed, but will be advertised in the medical papers in due course.

Competitors for the Bronze Medal and Prize of Ten Guiness must send in their essays to the President before 30th May, 1898.

The following candidates were successful at the November examination for the Nursing Certificate in addition to those published in the Jod RNAL for January, 1898 :

Valkenberg Asylum, South Africa.-Female : Ellen Kenny.

Port Alfred Asylum, South Africa.-Females: Fanny Maud Barnes, Louisa Annie Jane Evans, Edith Adeline Woods. Male: Valentine Muller.

\section{Notr.}

As the names of some of the persons to whom the Nursing Certificate has been granted by the Association have been removed from the Register, Employers are requested to refer to the Registrar in order to ascertain if a particular name is still on the Roll of the Association. In all inquiries the number of the Certificate should be given.

For further particulars respecting the various examinations of the Association apply to the Registrar, Dr. Spence, Burntwood Asylum, near Lichfield.

\section{NOTICES OF MEETINGS.}

MEDICO-PSTCHOLOGICAL ASSOCIATION.

The Annual Meeting of the Association will take place in Edinburgh, under the presidency of Dr. Urquhart, towards the end of July, and as the Aunual Meeting of the British Medical Association is also to be held in Edinburgh, it is considered that probably Thursday or Friday (or both), July 21st and 22nd, may be the most convenient dates, so as to enable members to attend both congresses.

As the success of the meeting depends upon the contributions of individual members, it is desirable that notices of discussions, exhibits, or papers to be read, be received at an early date, in order that the necessary arrangements may be made, and that facilities may be afforded to members seeking accommodation in kdinburgh during the meeting.

Notices of papers to be read or of intention to be present should therefore be sent as soon as possible to Dr. Turnbull, Hon. Secretary for Scotland, District Asylum, Cupar-Fife.

General Meeting.- The next General Meeting will be held at the rooms of the Association, 11, Chandos Street, Cavendish Square, London, W., on Thursday, May 12th, at 4 p.m., under the presidency of Dr. T. W. McDowall.

South-Western Division.-The Spring Meeting will be held in the County Asylum, Littlemore, Oxford, on Tuesday, the 19th April, 1898. The proposed alterations in the nursing regulations and the question of assured pensions will be discussed. Dr. Sankey will show cases, Drs. Noott and Blachford will contribute papers.

South-Eastern Division.-The next meeting will be held at the Wandsworth Asylum on the second or third Weduesday in April, 1898.

Northern and Midland Division.-The next meeting will be held in May, 1898.

BRITISH MEDICAL ASSOCIATION.

The sixty-sixth Annual Meeting will be held at Edinburgh from the 26th till the 29th July, 1898, under the presidency of Sir Thomas Grainger Stewart. Section of Psychology :-President, Thomas Smith Clouston, M.D. Vice-Presi- 